\title{
HISTOMORPHOMETRICAL EVALUATION IN TESTIS AND EPIDIDYMIS OF RATS WITH PULMONARY EMPHYSEMA EXPERIMENTALLY INDUCED BY PROLONGED EXPOSURE TO CIGARETTE SMOKE
}

\author{
AVALIAÇÃO HISTOMORFOMÉTRICA EM TESTÍCULO E EPIDÍDIMO DE RATOS \\ COM ENFISEMA PULMONAR INDUZIDO EXPERIMENTALMENTE POR \\ EXPOSIÇÃO PROLONGADA À FUMAÇA DE CIGARRO
}

\section{Amanda de Gênova RIBEIRO ${ }^{1}$; João Tadeu RIBEIRO-PAES ${ }^{2}$; Talita STESSUK ${ }^{3}$; Rodrigo de Las Heras KOZMA ${ }^{3}$; Isabel Cristina Cherici CAMARGO ${ }^{4}$}

1. Graduada em Ciências Biológicas, Universidade Estadual Paulista - UNESP, Assis, SP, Brasil; 2. Professor Assistente-Doutor, Departamento de Ciências Biológicas - UNESP, Assis, SP, Brasil; 3. Programa de Pós-graduação em Biotecnologia, Universidade de São Paulo - USP, São Paulo, SP, Brasil; 4. Professora Assistente-Doutora, Departamento de Ciências Biológicas, Universidade Estadual Paulista - UNESP, Assis, SP, Brasil. camargo@assis.unesp.br.

\begin{abstract}
The study evaluated the histomorphometrical aspects of testis and epididymis of adult rats with pulmonary emphysema experimentally induced by exposure to cigarette smoke for 30 weeks. Previous studies related to effects of the cigarette smoke on male reproductive tissue were performed in relatively shorter time periods and thus, it does not allow a direct correlation between smoke exposure and damage to reproductive structures like testis and epididymis. In order to evaluate the effect of cigarette smoke for long period on the testis and epididymis, twelve adult Wistar rats were divided into two groups: Control (CG; exposed to ambient air) and Smoking (SG; exposed to cigarette smoke). The weight of the testes, epididymides, seminal glands and prostate were not affected ( $\mathrm{p}>0.05)$ by experimental treatment. In the SG, the testes presented cellular desquamation, significant decrease in the number of germ cells and Sertoli cell, and reduction $(\mathrm{p}<0.05)$ in area and diameter of seminiferous tubules. The exposure of animals to cigarette smoke did not promoted histological changes in the epididymis, but decreased significantly the ductular area and epithelial height in the caput and corpus regions. It was concluded that testis was more susceptible than the epididymis to the effects of cigarette smoke constituents in rats with pulmonary emphysema experimentally induced by prolonged cigarette-smoke exposure.
\end{abstract}

KEYWORDS: Tobacco. Reproductive toxicology. Pulmonary emphysema. Comorbities.

\section{INTRODUCTION}

In accordance with the recent data of the World Health Organization, the number of smokers around the world is estimated at 1 billion people (WHO, 2013). In Brazil, the prevalence of smoking is $16 \%$, but a decline has been observed over the years (MALTA et al., 2010). However, globally, an increase of smoking is verified in less developed countries and the result is about 6 million deaths per year, the equivalent of 1 death every 6 seconds due to smoke exposure (WHO, 2013).

In this context, cigarette smoking is a serious public health problem and triggers an economic burden of more than half a trillion dollars per year. Still, smoking is considered a serious risk factor for six of the eight leading causes of death (WHO, 2013). Among the damage associated with cigarette constituents are reported heart and vascular diseases, asthma, tuberculosis, pulmonary emphysema, as well as cancer of the mouth, pharynx, larynx and lung (GREYDANUS; PATEL, 2003; WHO, 2013).
Chronic Obstructive Pulmonary Disease (COPD), which includes chronic bronchitis and pulmonary emphysema, is a major cause of mortality and morbidity, with high prevalence among the smoking adult population. The treatment of pulmonary emphysema, however, does not extend beyond palliative sphere and thus, the study in animal models with the aim of supporting new therapeutic strategies and broaden the understanding of the morphophysiological scope of the disease is considered of extreme scientific interest (RIBEIROPAES et al., 2011; FARIA et al., 2012; LONGHINIDOS-SANTOS et al., 2013; STESSUK et al., 2013).

Besides the adverse effects that constituents of cigarette cause to the cardiorespiratory system, are also widely reported effects on male reproduction. Among the several consequences, it is possible occur decrease in the quality and motility of sperm (SEPANIAK et al., 2004; MAHANEM et al., 2006; MEHRANNIA, 2007) and ultrastructural anomalies in the spermatids (AYDOS et al., 2001). Smoking also induces apoptosis in the testis of adult rats (DHABUWALA et al., 2002), which can be one of the mechanisms responsible for the defect in 
spermatogenesis after exposure to cigarette smoke (RAJPURKAR et al., 2002). This result may be related to the presence of various toxic substances in cigarette or histological reactions due to hypoxemia caused by smoking (AHMADNIA et al., 2007).

Cigarette smoking has a negative impact on male fertility (PASQUALOTTO et al., 2004), and studies confirm the passage of active components of the cigarette through hematotesticular barrier and these substances can induce a degradation of seminal parameters (SEPANIAK et al., 2004). Cigarette smoke also causes damage to the structure of the seminiferous tubules (RAJPURKAR et al., 2000; AUDI et al., 2006; MELLO et al., 2006). More studies should be conducted to assess the impact of cigarette smoke in the body and in male reproduction (AHMADNIA et al., 2007).

Reports in the literature demonstrate mainly the effects of cigarette smoke in animals during short periods of exposure (KAPAWA et al., 2004; MELLO et al., 2006; AHMADNIA et al., 2007). Furthermore, no study was conducted in the reproductive area to evaluate the male tissue of animals with pulmonary emphysema experimentally induced after prolonged exposure to cigarette smoke. In this context, the aim of this study was to evaluated, for first time, the structure of the testicular and epididymal tissue of rats with pulmonary emphysema induced by prolonged exposure to cigarette smoke, in order to integrate and establish a possible correlation between the smoking habit and histopathological effects on the testis and epididymis.

\section{MATERIAL AND METHODS}

\section{Animals and experimental groups}

Twelve male Wistar rats, 12-week old (weighing approximately $300 \mathrm{~g}$ ), were randomly distributed into two experimental groups: Control (CG; exposed to ambient air) and Smoking (SG; exposed to cigarette smoke).

The animals were kept in the Central Bioterium of UNESP - Universidade Estadual Paulista (Assis, São Paulo, Brazil), under conditions of standard environment (temperature of $22^{\circ} \mathrm{C} \pm$ $2^{\circ} \mathrm{C}$ and $12 \mathrm{~h}$ light/dark photoperiod). All animals received tap water and commercial solid diet ad libitum. The experimental protocol was approved by the Ethics Committee on Animal Use - CEUA (Permit number: 11/2011).

\section{Experimental protocol}

The protocol followed the model for emphysema induction reported by Kozma (2012), in which was used an inhalation chamber that consisted of an acrylic airtight box (70x70x30 cm), where the animals were kept during the experiment. The apparatus for cigarette smoke inhalation was composed of a combustion unit capable of burning one cigarette at a time. The animals were placed in compartments $(30 \times 20 \times 20 \mathrm{~cm})$ arranged inside the box and were exposed to mainstream smoke continuously (15 minutes), equivalent to four cigarettes, and to room air (5 minutes) during 3 hours per day, divided into three periods of 1 hour (ZHENG et al., 2009). The box presents an exhaustion system to prevent asphyxia of animals and for air renewal after each period of exposure to smoke. The experimental period lasted 30 weeks.

\section{Removal of organs and preparation of tissues}

At the end of 30 weeks period, the animals of each group were weighed and anesthetized at an overdose of thiopental sodium (Thiopentax ${ }^{\circledR}$, Cristalia, São Paulo, Brazil), intraperitoneally. The testes, epididymides, prostate complex (lateral, dorsal and ventral) and seminal glands were collected and weighed, obtaining the absolute $(\mathrm{g})$ and relative $(\mathrm{g} \%$; organ weight/final body weight $\mathrm{x}$ 100) weights of each organ.

The lung-heart block was removed in accordance with Kozma (2012). Briefly, the diaphragm was accessed, perforated and the chest was opened for release the heart-lung block.

The tracheas from heart-lung blocks were cannulated and connected to the perfusion apparatus for lung inflation under constant positive pressure with a $20 \mathrm{~cm}$ column of paraformaldehyde solution (4\%) during 24 hours for tissue fixation. The testes and epididymides were fixed in Bouin's solution for 24 hours. Thereafter, the organs were dehydrated in increasing ethanol solutions, clarified in xylol and embedded in Paraplast (Oxford Labware, St. Louis, USA). The 5- $\mu \mathrm{m}$-thick sections were stained with Hematoxylin and eosin (HE) and Mallory's Trichromic for histopathological examination.

\section{Morphometric analysis}

In each testis, ten cross-sections of seminiferous tubules/animal/group, at stage VIII of the seminiferous epithelium cycle (RUSSELL et al., 1990), were measured to obtain the following parameters: tubular diameter, epithelial height, luminal area and tubular area.

In the epididymis (left and right), in 10 cross-sections of each region (proximal caput, midcorpus and proximal cauda) were measured the following parameters: ductular area, luminal area and epithelial height. 
All measurements were performed in optical microscope Scope A1-Axio coupled with videocamera AxioCam ICc3 (Carl Zeiss, Germany) and digitalized by the software Axio Vision, version 4.7.2.

\section{Germ cells population analysis}

Germ cells (A type spermatogonia, primary spermatocytes in pachytene and round spermatids) and Sertoli cells with evident nucleolus were quantified in 10 cross-sections of seminiferous tubules at stage VIII of the seminiferous epithelium cycle (RUSSELL et al., 1990), as described by Foletto et al. (2010). The results were expressed as absolute numbers of each cell type.

\section{Statistical analysis}

The results were analyzed through parametric analysis of variance (ANOVA) complemented with the t-Student test, and were expressed as the mean \pm standard deviation (SD). When the data presented absent of normality, was
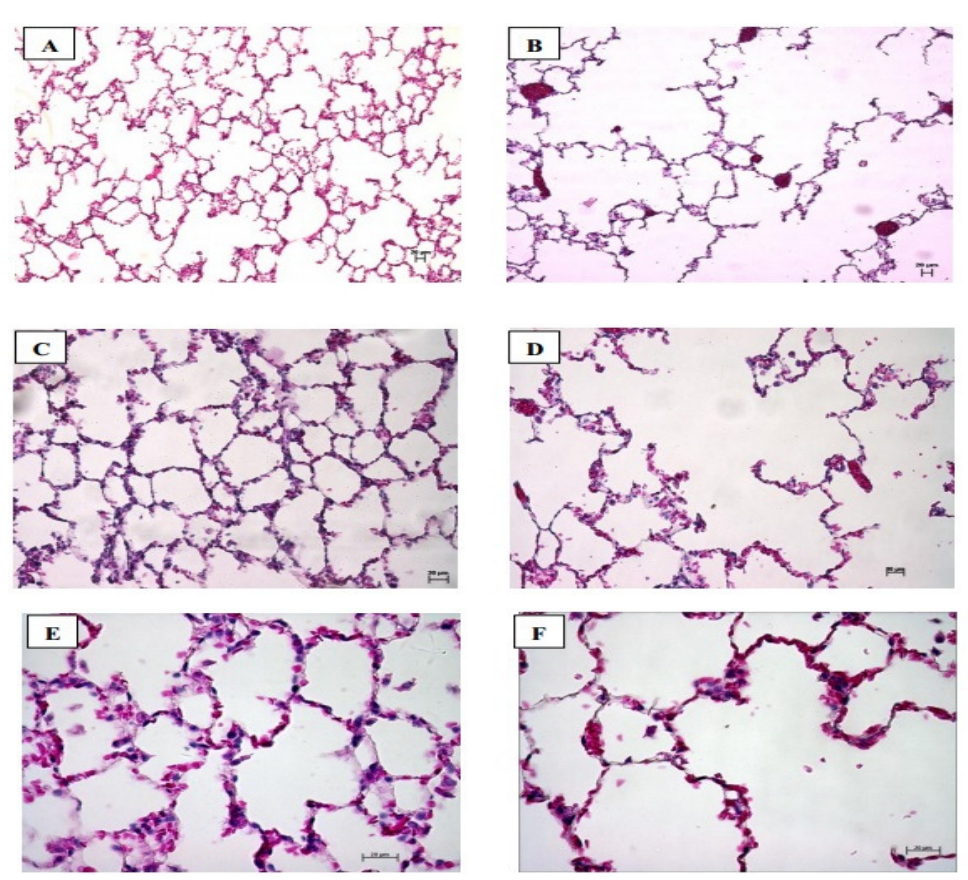

Figure 1. Photomicrographs of rat lung in the experimental groups: CG (A, C, E) and SG (B, D, F). Observe in SG the increase in alveolar area and destruction of parenchyma. Hematoxylin-eosin (HE). (KOZMA, 2012; KOZMA et al., 2014).

\section{Weight of the reproductive organs}

Absolute and relative weights of the testes, epididymides, full and empty seminal glands and prostate, are shown in Table 1. There was not effect significant $(\mathrm{p}>0.05)$ of exposure to cigarette smoking on the organ weight. employed the nonparametric Mann-Whitney test, and were expressed as the median \pm interquartile deviation. Statistical significance was set at $P<$ 0.05 .

\section{RESULTS}

\section{Pulmonary emphysema}

Figure 1 shows sections of lung tissue in both experimental groups. The alveoli were characteristically normal in CG-group, while in SGgroup there was increase in alveolar area and destruction of parenchyma, confirming the clinical findings of pulmonary emphysema. 
blood vessels and various other cells characteristic this tissue. On the other hand, in animals from SGgroup (Figures 2B, D), there was disruption of the seminiferous epithelial cytoarchitecture and the tubules exhibited immature germ cells in the lumen, represented mainly by primary spermatocytes and round spermatids, usually mixed with the residual bodies.

The Leydig cells showed normal aspect. The population of A type spermatogonia, spermatocytes in pachytene, round spermatids and Sertoli cells in the SG-rats was reduced $(\mathrm{p}<0.05)$, when compared to CG (Table 2).

Table 1. Absolute $(\mathrm{g})$ and relative $(\mathrm{g} \%)$ weights of the reproductive organs of CG and SG rats.

\begin{tabular}{lcc}
\hline Parameters & CG & SG \\
\hline Testes & $3.49 \pm 0.19$ & $3.46 \pm 0.35$ \\
G & $0.67 \pm 0.11$ & $0.69 \pm 0.06$ \\
g \%* & & \\
Epididymides & $1.42 \pm 0.09$ & $1.36 \pm 0.21$ \\
G & $0.27 \pm 0.03$ & $0.27 \pm 0.02$ \\
g\% & & \\
Full seminal glands & $2.11 \pm 0.42$ & $1.93 \pm 0.81$ \\
G & $0.40 \pm 0.06$ & $0.37 \pm 0.12$ \\
g\%* & & \\
Empty seminal glands & $1.13 \pm 0.22$ & $0.88 \pm 0.44$ \\
G & $0.21 \pm 0.04$ & $0.17 \pm 0.07$ \\
g\% & & \\
Prostate & $0.96 \pm 0.27$ & $1.11 \pm 0.41$ \\
G & $0.18 \pm 0.04$ & $0.21 \pm 0.07$ \\
g \% & & \\
\hline
\end{tabular}

Values are expressed as mean $\pm \mathrm{SD}$ (t-Student test). *Values are expressed as median \pm interquartile deviation (Mann-Whitney test). None statistical difference between the experimental groups $(P<0.05)$. CG: Control group; SG: Smoking group.

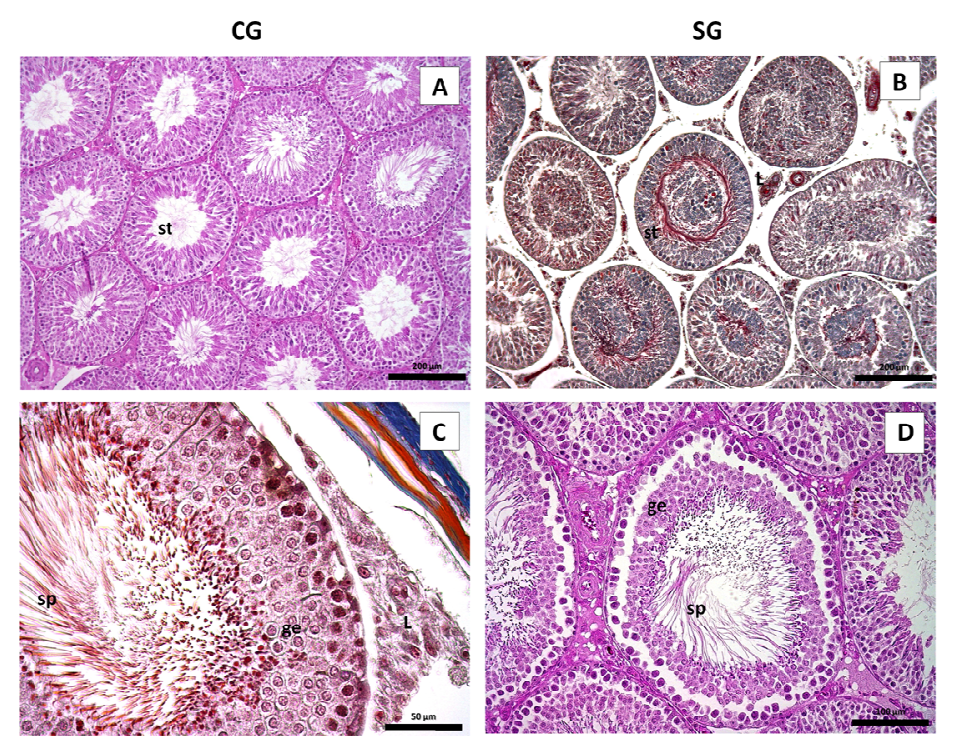

Figure 2. Photomicrographs of rat testis in the experimental groups: CG (A, C) and SG (B, D). Observe the absent of morphological integrity of seminiferous tubules (st) and cellular desquamation in the SGgroup. Germ epithelium (ge); spermatozoa (sp); Leydig cell (L). Hematoxylin-eosin (A, D); Mallory's Trichromic (B, C). 
Table 2. Quantification, in absolute numbers, of the cellular types in both groups.

\begin{tabular}{ccc}
\hline Cell type & CG & SG \\
\hline A spermatogonia & $2.8 \pm 0.87 \mathrm{a}$ & $1.88 \pm 0.76 \mathrm{~b}$ \\
Primary spermatocytes in pachytene & $65 \pm 19 \mathrm{a}$ & $38 \pm 11 \mathrm{~b}$ \\
Rounds spermatids & $117.48 \pm 16.37 \mathrm{a}$ & $72.56 \pm 14.06 \mathrm{~b}$ \\
& & $5.5 \pm 2 \mathrm{a}$ \\
Sertoli cells & & $5 \mathrm{~b}$
\end{tabular}

Within each line, values followed by different letters indicate statistical differences between the groups $(P<0.05)$. Values are expressed as the median \pm interquartile deviation. Mann-Whitney test. CG: Control group; SG: Smoking group.

The tubular diameter and area were significantly lower $(\mathrm{p}<0.05)$ in the group exposed to cigarette smoke, compared to the control group
(Table 3), but the epithelial height and luminal area were similar $(\mathrm{p}>0.05)$ in both groups.

Table 3. Testicular morphometric analysis of CG and SG rats.

\begin{tabular}{lll}
\hline Parameters & CG & SG \\
\hline
\end{tabular}

Mean tubular diameter $(\mu \mathrm{m})$

Epithelial height*

( $\mu \mathrm{m})$

Luminal area*

$\left(\mu \mathrm{m}^{2}\right)$

Tubular area*

$\left(\mu \mathrm{m}^{2}\right)$

$$
287.09 \pm 38.54 \mathrm{a}
$$

$71.81 \pm 25.10 \mathrm{a}$

$12101.9 \pm 9342.3 \mathrm{a}$

$65401.8 \pm 18309.9 a$
$273.84 \pm 33.62 b$

$74.59 \pm 17.66 \mathrm{a}$

$11352.9 \pm 7481.0 \mathrm{a}$

Within each line, values followed by different letters indicate statistical differences between the groups $(P<0.05)$. Values are expressed as the mean $\pm \mathrm{SD}$ (t-Student test). *Values are expressed as the median \pm interquartile deviation (Mann-Whitney test). CG: Control group; SG: Smoking group.

\section{Epididymis tissue}

In the CG and SG animals, the ductular morphological pattern was similar in the three regions. At the caput of the epididymis (Figures 3A, B) the duct presented high epithelium, extensive stereocilia and population of principal, basal, apical and narrow cells. In the corpus, the ductular epithelium becomes thinner (Figures 3C, D) consisting of principal, apical, clear, basal and halo cells. In the cauda (Figures $3 \mathrm{E}, \mathrm{F}$ ), the ductular area expanded considerably, as well as lumen, stereocilia become shorter than the corpus region and the epithelium presented itself very thin with principal, basal and clear cells. Abundant quantify of spermatozoa were present in the lumen.

The morphometrical analysis showed that ductular area and epithelial height were significantly lower $(\mathrm{p}<0.05)$ in the $S G$ rats compared to the $C G$, in the caput and corpus (Table 4 ). In the cauda there was no significant difference $(p>0.05)$ in the morphometric parameters among the experimental groups. 


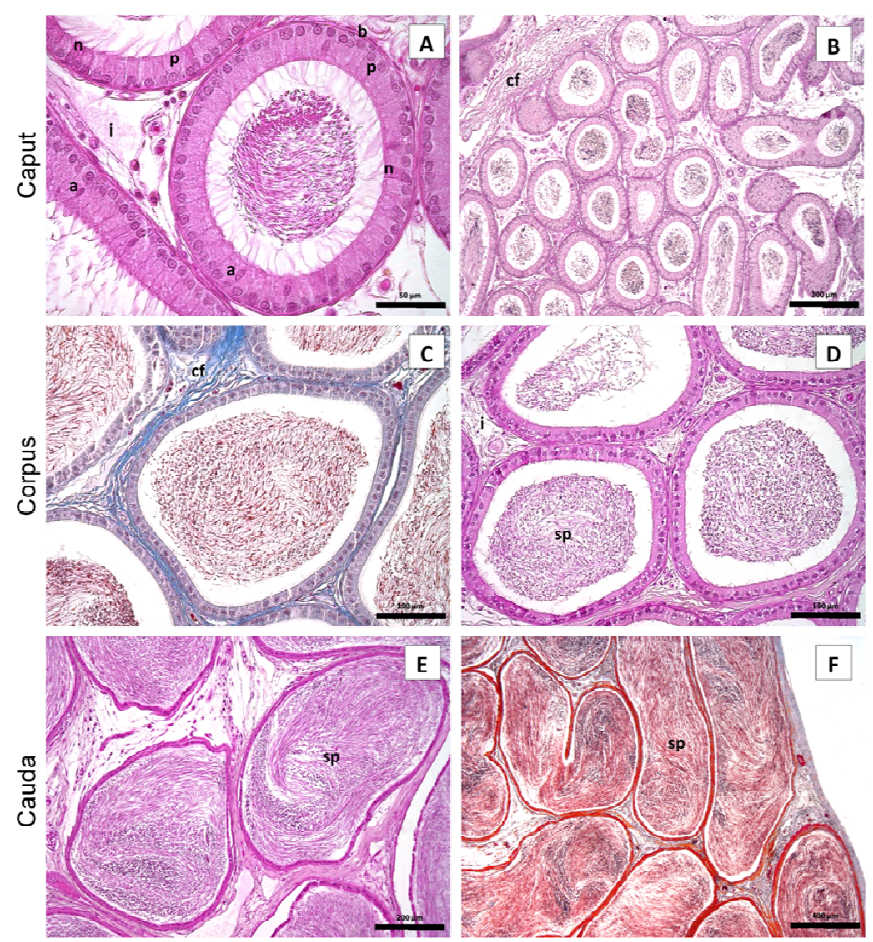

Figure 3. Photomicrographs of rat epididymis in the experimental groups: CG (A, C, E) and SG (B, D, F). In both groups are shown the regions of the proximal caput, mid-corpus and proximal cauda with similar morphological characteristics. Principal (p), apical (a), basal (b) and narrow (n) cells; collagen fibers (cf); interstitial tissue (i); spermatozoa (sp). Hematoxylin-eosin (A, B, D, E); Mallory's Trichromic (C, F).

Table 4. Morphometric analysis in the epididymis of CG and SG rats, in different regions of the organ.

\begin{tabular}{ccc}
\hline Parameters & CG & SG \\
\hline CAPUT & $28831.9 \pm 5163.5 \mathrm{a}$ & $22962.8 \pm 6679.4 \mathrm{~b}$ \\
Ductular area $\left(\mu \mathrm{m}^{2}\right)$ & $13670.1 \pm 3672.2 \mathrm{a}$ & $12796.4 \pm 6601.5 \mathrm{a}$ \\
Luminal area $\left(\mu \mathrm{m}^{2}\right)$ & $29.6 \pm 7.3 \mathrm{a}$ & $21.4 \pm 6.7 \mathrm{~b}$ \\
Epithelial height $(\mu \mathrm{m})$ & & \\
CORPUS & $93474.1 \pm 57622,3 \mathrm{a}$ & $78992.8 \pm 39963.7 \mathrm{~b}$ \\
Ductular area $\left(\mu \mathrm{m}^{2}\right)$ & $68511.2 \pm 55265,7 \mathrm{a}$ & $70078.4 \pm 29860.5 \mathrm{a}$ \\
Luminal area $\left(\mu \mathrm{m}^{2}\right)$ & $21.0 \pm 8.6 \mathrm{a}$ & $17.2 \pm 5.9 \mathrm{~b}$ \\
Epithelial height $(\mu \mathrm{m})$ & & \\
CAUDA & $179730.4 \pm 154129.5 \mathrm{a}$ & $190782.6 \pm 94352.0 \mathrm{a}$ \\
Ductular area $\left(\mu \mathrm{m}^{2}\right)$ & $156110.9 \pm 41754.1 \mathrm{a}$ & $189316.9 \pm 83150.0 \mathrm{a}$ \\
Luminal area $\left(\mu \mathrm{m}^{2}\right)$ & $17.0 \pm 4.8 \mathrm{a}$ & $16.0 \pm 4.1 \mathrm{a}$ \\
\hline
\end{tabular}

Within each line, values followed by different letters indicate statistical differences between the groups $(P<0.05)$. Values are expressed as the median \pm interquartile deviation. Mann-Whitney test. CG: Control group; SG: Smoking group. 


\section{DISCUSSION}

Cigarette smoking presents high prevalence among the adult population (WHO, 2013). Previous studies have reported decreased testis weight of rats exposed to cigarette smoke (RAJPURKAR et al., 2000; KAPAWA et al., 2004), similarly to animals treated with nicotine (LONDONKAR et al., 1998; AUDI et al., 2006). Lima et al. (2012) showed histopathological changes in testis and epididymis of rats exposed to cigarette smoke and proposed a possible correlation with the high rate of infertility in men smokers. Numerous investigations were composed for the effects of cigarette smoking on impaired spermatogenesis (YÜKSEL et al., 2014). The exposure protocols adopted in these studies were short and ranged from 45 days to 10 weeks (RAJPURKAR et al., 2002; KAPAWA et al., 2004; AHMADNIA et al., 2007), whereas in the present study the animals were exposed to smoke cigarette during a prolonged time. In this scenario, it is sought with this study to determine, in a new experimental model, possible deleterious effects to the reproductive tissue resulting from prolonged exposure to cigarette smoke. Then, was adopted a prolonged and intense period of exposure for 30 weeks, with 3 sessions of daily exposure (1 hour each session) during all days of the week.

In this study, there were histopathological changes in the testis of animals exposed to smoke (SG), but the gonad weight was similar to the control group (CG). On the basis of these findings it is possible to conclude that the testicular tissue was affected even before to result in changes in the weight.

Although it is reported that nicotine decreases the weight of the sexual glands and epididymis (LONDONKAR et al., 1998; LIMA et al., 2012), in present study, the weight of androgendependent glands, such as, epididymis, prostate and seminal glands was not affected by prolonged exposure to cigarette smoke. The differences in the experimental protocols contributed possibly by discrepancy in the results.

The spermatogenesis is a sensitive process to exogenous and endogenous agents because it involves division and cell differentiation. Previous reports described that cigarette smoke exposure affected the testicular tissue of adult animals, having the presence of only one layer of cells or few germ cells in the seminiferous epithelium (AUDI et al., 2006), as well as reduction in Sertoli cells number (MELLO et al., 2006). Also, exposure to tobacco smoke during intrauterine period promoted a significant increase in the incidence of Sertoli cell and germ cell apoptosis, detected by caspase-3 immunostaining (YÜKSEL et al., 2014). The results of present study confirm previous report, since there was loss of integrity of the seminiferous epithelium and cellular desquamation in the animals exposed to cigarette smoke. Moreover, the population of A type spermatogonia, spermatocyte I in pachytene, round spermatids and Sertoli cells was reduced in the Smoking Group. According Reddy et al. (1998) the decrease in the number of spermatocytes and spermatids in the testis of mice treated with nicotine may occur probably due to lack of pituitary gonadotropins, essentials to the processes of spermatogenesis and steroidogenesis. Sepaniak et al. (2004) reported that the loss of germ cells may be due to the passage of active constituents of cigarette through hematotesticular barrier.

The morphometric analysis of testes from SG-rats demonstrated decreased in tubular diameter and area, confirming the occurrence of atrophy of seminiferous tubules promoted by cigarette smoke (RAJPURKAR et al., 2000; MELLO et al., 2006).

In this study, none injury in epididymis tissue was observed in the animals exposed to cigarette smoke during the prolonged and intense period of 30 weeks. However, there was a decrease in the ductular area and epithelial height at the caput and corpus, representing regions of gamete transport. In the cauda, site of maturation and storage of spermatozoa, none morphometric parameter was affected by exposure to cigarette smoke. Although the nicotine, component more toxic of cigarettes, promotes vascular congestion in the epididymis (LIMA et al., 2012), and reduces the number of gametes in the lumen (MAHANEM et al., 2006), such effects were not observed in the rats exposed to cigarette smoke. In these animals, the maintenance of tissue integrity indicated absent of deleterious effects promoted by chemical constituents of the smoke on the epididymis. However, future studies are required to assess the functional status of the organ as well as the sperm parameters of animals exposed to cigarette smoke in the experimental conditions of this study.

A number of diseases coexist with COPD (comorbidities) such as cardiovascular disease, osteoporosis, gastroesophageal reflux and weight loss (GOLD, 2016). Considering the set of extrapulmonary pathological manifestations, the current trend is to consider COPD as a systemic disease (SIN et al, 2006; ALMAGRO et al, 2012). Many studies have established a strong correlation between smoking and its side effects on reproduction, but no previous report included the 
morphologic changes of the reproductive system as a coexisting pathological change with COPD / emphysema. Then, based on the results this study can be proposed that the changes in the male reproductive system can also be included as comorbidities present in COPD.

\section{CONCLUSIONS}

The present study showed that in the rats with pulmonary emphysema experimentally induced by prolonged exposure to cigarette smoke, the testis was most susceptible to the epididymis to chemicals constituents of cigarette.

The exposure to cigarette smoke promoted histomorphometrical changes in the testicular tissue, but in epididymal tissue the changes occurred only in the ductular area and epithelial height at the caput and corpus, such that further studies should be performed to evaluate the functional aspects of organ.

Finally, the results allow inferring that changes in the reproductive system may be included as comorbidities present in COPD.

RESUMO: O estudo avaliou os aspectos histomorfométricos dos testículos e epidídimos de ratos adultos induzidos experimentalmente ao enfisema pulmonar por exposição à fumaça de cigarro, durante 30 semanas. Estudos prévios relacionados aos efeitos da fumaça de cigarro sobre o aparelho reprodutor masculino foram realizados com tempos de exposição relativamente curtos e, dessa forma, não permitem estabelecer uma correlação direta entre exposição à fumaça e danos às estruturas reprodutoras, como testículo e epidídimo. Buscando, portanto, avaliar o efeito da fumaça de cigarro sobre os testículos e epidídimos de animais expostos por longos períodos à fumaça de cigarro, doze ratos albinos da linhagem Wistar foram divididos em dois grupos: Controle (GC; expostos ao ar ambiente) e Tabagista (GT; expostos à fumaça de cigarro). Os pesos dos testículos, epidídimos, glândulas seminais e próstata não foram afetados ( $\mathrm{p}>0,05)$ pelo tratamento experimental. No GT, os testículos apresentaram descamação celular, diminuição significativa no número de células germinativas e células de Sertoli, além de uma redução $(\mathrm{p}<0,05)$ na área e diâmetro dos túbulos seminíferos. A exposição dos animais à fumaça de cigarro não promoveu alterações histológicas nos epidídimos, mas diminuiu significativamente a área ductular e a altura epitelial nas regiões de cabeça e cauda. Concluiu-se que os testículos foram mais susceptíveis do que os epidídimos aos efeitos dos constituintes da fumaça de cigarro em ratos induzidos experimentalmente ao enfisema pulmonar.

PALAVRAS-CHAVE: Fumaça de cigarro. Toxicologia reprodutiva. Enfisema pulmonar. Comorbidades.

\section{REFERENCES}

ALMAGRO, P.; CABRERA, F. J.; DIEZ, J.; BOIXEDA, R.; ALONSO ORTIZ, M. B.; MURIO, C.; SORIANO, J. B.; WORKING GROUP ON COPD. SPANISH SOCIETY OF INTERNAL MEDICINE. Comorbidities and short-term prognosis in patients hospitalized for acute exacerbation of COPD: the EPOC en Servicios de medicina interna (ESMI) study. Chest. Chicago. v. 142, n. 5, p. 1126-1133, 2012.

http://www.ncbi.nlm.nih.gov/pubmed/23303399

AHMADNIA, H.; GHANBARI, M.; MORADI, M. R.; KHAJE, D. M. Effect of cigarette smoke on spermatogenesis in rats. Urol J. Tehran, v. 4, n. 3, p. 159-163, 2007. http://citeseerx.ist.psu.edu/viewdoc/download?doi=10.1.1.607.8069\&rep=rep1\&type=pdf

AUDI, S. S.; ABRAHAM, M. E.; BORKER, A. S. Effect of cigarette smoke on body weight, food intake and reproductive organs in adult albino rats. Indian J Exp Biol. New Delhi, v. 44, n. 7, p. 762-565, 2006. http://www.ncbi.nlm.nih.gov/pubmed/16872045

AYDOS, K.; GUVEN, M. C.; CAN, B.; ERGÜN, A. Nicotine toxicity to the ultrastructure of the testis in rats. BJU Int. Edinburgh, v. 88, n. 6, p. 622-626, 2001. http://onlinelibrary.wiley.com/doi/10.1046/j.14644096.2001.02384.x/full

BARNES, P. J. New concepts in chronic obstructive pulmonary disease. Ann Rev Med. Palo Alto, v. 54, p. 113-129, 2003. http://www.ncbi.nlm.nih.gov/pubmed/12359824 
DHABUWALA, C. B.; DUNBAR, J. C.; LI, H.; RAJPURKAR, A.; JIANG, Y. Cigarette smoking induces apoptosis in rat testis. J Environ Pathol Toxicol Oncol. New York, v. 21, n.3, p. 243-248, 2002. http://www.dl.begellhouse.com/journals/0ff459a57a4c08d0,255a6a8328e9902e,7899ec13020a5817.html

FARIA, C. A.; KOZMA, R. H.; STESSUK, T.; RIBEIRO-PAES, J. T. Experimental basis and new insights for cell therapy in Chronic Obstructive Pulmonary Disease. Stem Cell Rev. Bethesda, v. 8, n. 4, p. 1236-1244, 2012. http://www.ncbi.nlm.nih.gov/pubmed/23054962

FOLETTO, M. P.; MAREZE-COSTA, M.; FERRARI, F.; FRANZÓI-DE-MORAES, S.; SEGATELLI, T. M. Effect of the nandrolone decanoate on the efficiency of spermatogenesis of sedentary rats and rats subjected to physical training. Acta Scientiarum Health Sci. Maringá, v. 32, n. 1, v. 17-22, 2010.

http://periodicos.uem.br/ojs/index.php/ActaSciHealthSci/article/view/5741

FUNK, D.; MARINELLI, P. W.; LÊ, A. D. Biological processes underlying co-use of alcohol and nicotine: neuronal mechanisms, cross-tolerance, and genetic factors. Alcohol Res Health. Rockville, v. 29, n. 3, p. 186192, 2006. http://www.ncbi.nlm.nih.gov/pubmed/17373407

GONÇALVES-SILVA, R. M. V.; LEMOS-SANTOS, M. G.; BOTELHO, C. Influência do tabagismo no ganho ponderal, crescimento corporal, consumo alimentar e hídrico de ratos. J Pneumol. Brasília, v. 23, n. 3, p. 124130, 1997. http://jornaldepneumologia.com.br/PDF/1997_23_3_3_portugues.pdf

GLOBAL INITIATIVE FOR CHRONIC OBSTRUCTIVE PULMONARY DISEASE - GOLD [Internet]. Pocket guide to COPD diagnosis, management, and prevention. 2015 [cited from: 2016 Jun 1]. Available from: http://www.goldcopd.it/materiale/2015/GOLD_Pocket_2015.pdf

GREYDANUS, D. E.; PATEL, D. R. Substance abuse in adolescents: a complex conundrum for the clinician. Pediatr Clin North Am. Bethesda, v. 50, n. 5, p. 1179-1223, 2003.

http://www.ncbi.nlm.nih.gov/pubmed/14558685

KAPAWA, A.; GIANNAKIS, D.; TSOUKANELIS, K.; KANAKAS, N.; BALTOGIANNIS, D.; AGAPITOS, E.; LOUTRADIS, D.; MIYAGAWA, I.; SOFIKITIS, N. Effects of paternal cigarette smoking on testicular function, sperm fertilizing capacity, embryonic development, and blastocyst capacity for implantation in rats. Andrologia. Berlin, v. 36, n. 2, p. 57-68, 2004. http://www.ncbi.nlm.nih.gov/pubmed/15084151

KOZMA, Rodrigo de las Heras. Modelo experimental de indução de enfisema pulmonar por exposição à fumaça de cigarro. 2012. 67 f. Dissertação (Mestrado em Biotecnologia) - Curso de Pós-Graduação Interunidades em Biotecnologia, Instituto de Ciências Biomédicas, Universidade de São Paulo, São Paulo, 2012. www.teses.usp.br/teses/disponiveis/.../RodrigoLasHerasKozma_Mestrado_Corrigida.pdf

KOZMA, R. H.; ALVES, E. M.; BARBOSA-DE-OLIVEIRA, V. A.; LOPES, F. D. T. Q.; GUARDIA, R. C.; BUZO, H. V.; FARIA, C. A.; YAMASHITA, C.; CAVAZZANA JUNIOR, M.; FREI, F.; RIBEIRO-PAES, M. J. O.; RIBEIRO-PAES, J. T. A new experimental modelo of cigarette smoke-induced emphysema in Wistar rats. J Bras Pneumol. Brasília, v. 40, n. 1, p. 46-54, 2014. http://www.scielo.br/scielo.php?pid=S180637132014000100046\&script=sci_arttext\&tlng=pt

LIMA, V. M.; BARBIERI, R. L.; AQUILA, A. D.; MYAMORA, F.; DUARTE, I. S. Estudo histopatológico do efeito da nicotina nos testículos e epidídimos de ratos. Rev Bras Clin Med. São Paulo, v. 10, n. 4, p. 322-328, 2012. http://bases.bireme.br/cgi-

$\mathrm{bin} / \mathrm{wxislind}$. exe/iah/online/?IsisScript=iah/iah.xis\&src=google\&base=LILACS\&lang=p\&nextAction=lnk\&exp rSearch $=646055 \&$ indexSearch $=$ ID

LONDONKAR, R. S.; SRINIVASREDDY, P.; SOMANATHREDDY, P.; PATIL, S. B. Nicotine induced inhibition of the activities of accessory reproductive ducts in male rats. J Ethnopharmacol. Limerick, v. 60, n. 3, p. 215-221, 1998. http://www.ncbi.nlm.nih.gov/pubmed/9613835 
LONGHINI-DOS-SANTOS, N.; BARBOSA-DE-OLIVEIRA, V. A.; KOZMA, R. H.; FARIA, C. A.; STESSUK, T.; FREI, F.; RIBEIRO-PAES, J. T. Cell therapy with bone marrow mononuclear cells in elastaseinduced pulmonary emphysema. Stem Cell Rev. Bethesda, v. 9, n. 2, p. 210-218, 2013.

http://www.ncbi.nlm.nih.gov/pubmed/23242964

MAHANEM, M. N.; NOR-ASMANIZA, A. B.; PHANG, H. T.; MUHAMMAD, H. R. Effects of nicotine and co-administration of nicotine and vitamin $\mathrm{E}$ on testis and sperm quality of adult rats. Malays Appl Biol J. Selangor, v. 35, n. 2, p. 47-52, 2006.

http://mabjournal.com/index.php?option=com_content \&view=article \&id=367\&catid=59:currentview\&Itemid $=56$

MALTA, D. C.; MOURA, E. C.; SILVA, A. S.; OLIVEIRA, P. P. V.; COSTA E SILVA, V. J. L. Prevalência do tabagismo em adultos residentes nas capitais dos estados e no Distrito Federal. Brasil. Braz J Pneumol. Brasília, v. 36, n. 1, p. 75-83, 2010. http://www.scielo.br/scielo.php?script=sci_arttext\&pid=S180637132010000100013

MEHRANNIA, T. The effect of cigarette smoking on semen quality of infertile men. Pak J Med Sci. Karachi, v. 23, n. 5, p. 717-719, 2007. http://www.pjms.com.pk/issues/octdec107/article/article13.html

MENEZES, A. M. B. Diretrizes para cessação do tabagismo. J Bras Pneumol. Brasília, v. 30, p. s2-s76, aug. 2004. Supplement 2.

http://jornaldepneumologia.com.br/PDF/Suple_92_16_consenso\%20tabagismo\%202004.pdf

MELLO, P. R. B.; OKAY, T. S.; BOTELHO, C. A. Influência da exposição à fumaça lateral do cigarro sobre o ganho de peso e o consumo alimentar de ratas gestantes: análise do peso e do comprimento dos filhotes ao nascimento. Rev Bras Ginecol Obstet. Rio de Janeiro, v. 28, n. 3, p. 143-150, 2006.

http://www.scielo.br/scielo.php?script=sci_arttext\&pid=S0100-72032006000300002

PASQUALOTTO, F. F.; LUCON, A. M.; SOBREIRO, B. P.; PASQUALOTTO, E. B.; ARAP, S. Effects of medical therapy, alcohol, smoking, and endocrine disruptors on male infertility. Rev Hosp Clin Fac Med São Paulo. São Paulo, v. 59, n. 6, p. 375-382, 2004. http://www.scielo.br/scielo.php?script=sci_arttext\&pid=S004187812004000600011

PAUWELS, R. A.; BUIST, A. S.; CALVERLEY, P. M.; JENKINS, C. R.; HURD, S. S.; GOLD SCIENTIFIC COMMITTEE. Global strategy for the diagnosis, management, and prevention of chronic obstructive pulmonary disease. NHLBI/WHO Global Initiative for chronic obstructive lung disease (GOLD) Workshop summary. Am J Respir Crit Care Med. New York, v. 163, n. 5, p. 1256-1276, 2001.

http://www.pagni.gr:8081/PneumoWeb/Gold.pdf

RAJPURKAR, A.; JIANG, Y.; DHABUWALA, C. B.; DUNBAR, J. C.; LI, H. Cigarette smoking induces apoptosis in rat testis. J Environ Pathol Toxicol Oncol. New York, v. 21, n. 3, p. 243-248, 2002. http://www.ncbi.nlm.nih.gov/pubmed/12435077

REDDY, S.; LONDONKAR, R.; RAVINDRA, R. S.; PATIL, S. B. Testicular changes due to graded doses of nicotine in albino mice. Indian J Physiol Pharmacol. New Delhi, v. 42, n. 2, p- 276-280, 1998. http://www.ncbi.nlm.nih.gov/pubmed/10225057

RIBEIRO-PAES, J. T.; BILAQUI, A.; GRECO, O. T.; RUIZ, M. A.; MARCELINO, M. Y.; STESSUK, T.; FARIA, C. A.; LAGO, M. R. Unicentric study of cell therapy in chronic obstructive pulmonary disease/pulmonary emphysema. Int J Chron Obstruct Pulmon Dis. Bethesda, v. 6, p. 63-71, 2011. http://www.ncbi.nlm.nih.gov/pmc/articles/PMC3034284/

RUSSELL, L. D.; ETTLIN, R. A.; SINHA-HIKIM, A. P.; CLEGG, E. D. Histological and histopathological evaluation of the testis. In: RUSSELL, L. D.; ETTLIN, R. A.; SINHA-HIKIM, A. P.; CLEGG, E. D. (Eds.). The classification and timing of spermatogenesis. Clearwater: Cache River Press, 1990. p. 41-57. 
SEPANIAK, S.; FORGES, T.; FONTAINE, B.; GERARD, H.; FOLIGUET, B.; GUILLET-MAY, F.; ZACCABRI, A.; MONNIER, P. B. Negative impact of cigarette smoking on male fertility: from spermatozoa to the offspring. J Gynecol Obstet Biol Reprod. Paris, v. 33, n. 5, p.384-390, 2004.

http://www.ncbi.nlm.nih.gov/pubmed/15480277 . http://dx.doi.org/10.1016/S0368-2315(04)96545-3

SIN, D. D.; ANTHONISEN, N. R.; SORIANO, J. B.; AGUSTI, A. G. Mortality in COPD: Role of comorbidities. Eur Respir J. Sheffield. v. 28, n. 6, p. 1245-1257, 2006.

http://www.ncbi.nlm.nih.gov/pubmed/17138679

STESSUK, T.; RUIZ, M. A.; GRECO, O. T.; BILAQUI, A.; RIBEIRO-PAES, M. J. O.; RIBEIRO-PAES, J. T. Phase I clinical trial of cell therapy in patients with advanced chronic obstructive pulmonary disease: follow-up of up to 3 years. Rev Bras Hematol Hemoter. São Paulo, v. 35, n. 5, p. 352-357, 2013.

http://www.ncbi.nlm.nih.gov/pubmed/24255620

WHO - Fact sheet N 339: Tobacco (Internet) World Health Organization (Updated July 2013). http://www.who.int/mediacentre/factsheets/fs339/en/

YÜKSEL, B.; KILIC, S.; LORTLAR, N.; TASDEMIR, N.; SERTYEL, S.; BARDAKCI, Y.; AKSU, T.; BATIOGLU, S. Environmental tobacco smoke exposure during intrauterine period, promotes caspase dependent and independent DNA fragmentation in Sertoli-germ cells. ISRN Obstet Gynecol. Bethesda, v. 2014, n. 170124, 2014. http://www.ncbi.nlm.nih.gov/pubmed/25045542

ZHENG, H.; LIU, Y.; HUANG, T.; FANG, Z.; LI, G.; HE, S. Development and characterization of a rat model of chronic obstructive pulmonary disease (COPD) induced by side stream cigarette smoke. Toxicol Lett. Amsterdam, v.189, n. 3, p. 225-234, 2009. http://www.ncbi.nlm.nih.gov/pubmed/19524650 